\title{
STRUCTURAL VARIABLE ON THE JOB SATISFACTION OF 4 AND 5 STARRED HOTEL EMPLOYEES IN SURABAYA
}

\author{
Agustinus Nugroho \\ Endo Wijaya Kartika \\ Thomas Stefanus Kaihatu \\ Management Department of Petra Christian University \\ J1. Siwalankerto 121-131, Surabaya 60236 \\ Email: endo@petra.ac.id
}

\begin{abstract}
The study aimed to find out the effect of management's controllable factor, which was called internal factor or structural variable, on the job satisfaction of the 4 and 5 starred hotel employees' in Surabaya. The study used quantitative explanative technique to explain the effect of structural variable on employees' job satisfaction. The result showed that structural variable had a positive and significant effect on job satisfaction. It is also found that employees' job satisfaction was high when there was (or the highest indicator for structural variable was) fellow employees' support and supervisor's support, while the lowest indicator was job routine; the highest indicator for job satisfaction was satisfaction in salary, while the lowest indicator was supervisor's competency in performing his or her tasks.
\end{abstract}

Keywords: Structural Variable, Job Satisfaction, Hotel Employee

\begin{abstract}
Abstrak
Penelitian ini bertujuan menemukan pengaruh faktor yang dapat dikendalikan manajemen, yang disebut faktor internal atau variabel struktural terhadap kepuasan kerja karyawan hotel bintang 4 dan 5 di Surabaya. Penelitian ini menggunakan teknik kuantitatif eksplanatif. Hasilnya menunjukkan bahwa variabel struktural berpengaruh positif dan signifikan terhadap kepuasan kerja. Kepuasan kerja karyawan tinggi ketika terdapat (indikator tertinggi variabel struktural) dukungan dari rekan kerja dan dukungan penyelia. Indikator terendah ialah rutinitas kerja. Indikator tertinggi kepuasan kerja ialah kepuasan akan gaji dan indikator terendah ialah kompetensi penyelia dalam menjalankan tugasnya.
\end{abstract}

Kata Kunci: Variabel Struktural, Kepuasan Kerja, Karyawan Hotel

\section{INTRODUCTION}

Indonesia has become the destination of international tourists. The number of international visitors to Indonesia from year 2012 to year 2013 increased by 6\% ("Perkembangan Pariwisata dan Transportasi Nasional," Maret 2013 or "National Tourism and Transportation Development," March 2013), which proves that Indonesia is becoming more attractive to international tourists. This has an effect on the development of hotel industry in Indonesia, which is seen in the increase of local and foreign investors who build hotels in Indonesia (Purnomo, 2012)

The growth of the hotel industry also influences the city of Surabaya as Indonesia's second largest city. In 2011, the number of hotel rooms in Surabaya was predicted to increase with the building of 15 new hotels (Wahyuni, 2011). And in year 2012, the request of hotel building permits to the municipal government of Surabaya increased six times than the previous year ("30 Hotel Baru Menyerbu," 2012 or "30 New Hotels Attack the Hotel Industry," 2012).

This significant increase in the number of hotels in Surabaya certainly influences the competition among hotel brands, international and local (Wahyuni, 2011). Consequently, each hotel should have a competitive excellence in order to survive the competition (Kandampully \& Suhartanto, 2000). Kartika \& Kaihatu (2010) add that having a competitive excellence is necessary for the survival of an industrial undertaking, including the hotel business. One way of achieving competitive excellence is by own- 
ing and utilizing employees to realize the company's goals (Kotler \& Armstrong, 1997).

The paradigm that employees are burden to a company has changed. Today, employees and human resources are considered as important assets in a company's survival (Datta, 2012). The fact that the number of hotels has increased largely, automatically increases the demands for skillful hotel employees in various fields. In this case, it is important for hotels which already have employees with excellent performances to maintain their resources (Schwepker Jr., 2001). Thus, the hotel management should monitor the commitment level of the human resources who work in the hotel.

Riketta (2002) proposes that highly committed employees will give excellent work performance. Thus, it can be concluded that hotels with highly committed employees will have higher competitive excellence than other hotels. In order to obtain and maintain highly committed employees, a company should take care of the employees' job satisfaction (Currivan, 2000; Iverson \& Deery, 2007). In general, employees' job satisfaction can be regarded as a gap between employees' wishes and company's ability to meet that wishes (Timmreck, 2001). When a company is able to meet that wishes, employees will feel satisfied. Further, Currivan (2000) states that basically, a company management should take care of factors that can be controlled by the management, and also the uncontrollable factors from outside the company.

From the two factors mentioned above, we focus on the controllable variable, which is called internal factor or structural variable, which influences employees' job satisfaction. Hom \& Griffeth (1995) states that the managerial skills of a company in treating its employees will increase employees' job satisfaction. The company management should ascertain that employees have good perception of the system applied in the company. A good perception of the employees towards the management will influence employees' job satisfaction and in turn will raise employees' commitment to the hotel where they work (Iverson \& Deery, 2007).

Further, Iverson \& Deery (2007) propose that the first thing to be taken care of by the management is support from the management and from fellow employees towards an employee's performance. An employee who feels supported and is given feedbacks by the management will feel that he is working in a comfortable environment and will have definite goals in his job.

Second, the management should take care of the job routines (Iverson \& Deery, 2007). Concerning routines, Timmreck (2001) confirms that a well designed job will cause employees to feel comfortable with their jobs. Excessive routines will cause employees to feel bored and in turn will influence employees' performance.

Besides those two points, the management should take care of employees' perception of the management behavior towards them, which is called distributive justice. The most important factor in this perception is employees' perception of justice. There is a possibility that a decision which is considered just by the management is thought of differently by the employees.

Concerning the phenomenon, hotels in Surabaya should ascertain that their employees feel satisfied, which will raise employees' commitment to the management, and in turn will raise competitive excellence. This is not easy since high competitiveness causes high job opportunities. From interviews with three hotels' employees in Surabaya, we find that they do not feel satisfied with the work system applied by the hotel managements. From initial interviews we find that the most important point is the injustice of the management's treatment towards the employees. The employees also complain about their job routines which make the job boring.

Based on phenomena and facts obtained from interviews, we would like to study employees' perception of internal factors or structural variable of hotels in Surabaya. We will also discuss employees' satisfaction level to affirm the conclusion of the study.

\section{THEORETICAL BASE AND HYPOTHESES}

\section{The Concept of Job Satisfaction}

Cranny, Smith, \& Stone (1992) define job satisfaction as an emotional response towards a job. While Weiss (2002) proposes that job satisfaction is an attitude. Astrauskaite, Vaitkevičius, \& Perminas (2011) add that it is a response towards employees' performance evaluation. Mahardika (2006) states that "job satisfaction is an individual's orientation which influences his or her work role and job characteristic." Thus, we can conclude that job satisfaction is an employee's emotional attitude in his or her response towards employee's performance evaluation. This response is also affected by the employee's achievements.

Iverson \& Deery (2007) describe the factors which influence employees' job satisfaction as follows:

1. Structural variable is a factor which relates to work setting, both in the job itself and in the company's condition. The factor which influences structural variable is support from fellow emplo- 
yees and from the management (coworker and supervisory support), job routine and distributive justice.

In relation to structural variable, Timmreck (2001) states that a nice behavior towards employees will result in employees' job satisfaction. Job design also influences employees' satisfaction. This is mainly expressed in the complexity level of a job. If a job is too easy, employees may feel bored. However, if a job is too difficult and demand extreme physical strength, employees may feel surfeited.

2. Environmental factors are factors that cannot be controlled by a company in its effort to give job satisfaction to its employees. These factors relate to the environmental condition of the place where the employees live. Environmental factors are influenced by:

a. Job opportunity

The opportunity to find other jobs outside the company.

b. Turnover culture

Employees' belief that turnover is a common practice in industry.

c. Kinship responsibility

Direct responsibility towards employees' family or closest relatives.

Mahardika (2006) proposes that job satisfaction can be measured by salary, fellow employees, createvity, and independence, working condition, supervisor's competency, job autonomy, and opportunities for advancement. Sha (2007) adds that there are factors which influence job satisfaction, namely factors from outside and from inside the employee himself or herself. Sha states that the factors from inside the employee which are often called intrinsic factors have bigger influence on employee's job satisfaction.

The intrinsic factors which significantly influence job satisfaction are personjob fit and personality factors (Sha, 2007). Johns (1996) proposes that job satisfaction is a difference or gap between employee's performance and what is perceived as performance by the employee himself or herself. Spector (1997) states that the smaller the difference or gap, the higher the employee's job satisfaction. Thus, it can be concluded that the fitness level of an employee towards a job, or personjob fit is a factor which influences job satisfaction.

Aamodt (2004) states that beside personjob fit, an employee's character determines his or her job satisfaction, regardless of work environment or other factors. A previous study (Spector, 1997) shows that there are several employees who continuously complain although the management has taken many steps to ascertain the employees' job satisfaction. Aamodt (2004) proposes that in order to increase employees' job satisfaction globally inside a company, the recruitment system should be arranged so that the employees recruited are employees with good personalities. Sha (2007) confirms it with his finding which shows that there are many companies which continuously make efforts to raise job satisfaction, but because the employees do not have good personailities, the expected results are not achieved.

\section{Model of the Study}

The model of the study is as shown on Figure 1.

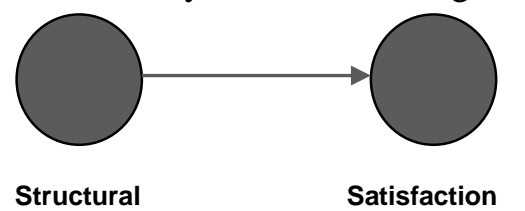

Figure 1. Model of the Study

\section{Hypothesis}

Based on the facts and phenomena which have been presented by previous studies (among others by Iverson \& Deery, 2007), we formulate the hypothesis that structural variable influences the job satisfaction of the employees of 4 and 5 starred hotels in Surabaya.

\section{RESEARCH METHOD}

This study employs quantitative explanative method with the employees of 4 and 5 starred hotels in Surabaya as the population. The sampling method is non probability sampling and judgmental sampling, with the following criteria: employees of the age older than 18 years and have worked for minimally three years. The sample utilized in this study amounts to 100 respondents, which meets the requirement of Sekaran (2006) who states that the valid sample amount for most studies are between 30-500 respondents.

The data collecting technique of this study is by distributing questionnaires directly to employees who meet the criteria. The questionnaire contains five options according to Likert Scale, where 1 indicates "strongly disagree" and 5 indicates "strongly agree" towards the statements in the questionnaire.

The data analysis technique utilized in this study is mean analysis where the mean values are previously grouped into class intervals from "very low", "low", "sufficiently high", "high", and "very high". Besides that, in order to describe job satisfaction, we also utilize mean analysis with the following classifycation: "very dissatisfied", "dissatisfied", "sufficiently satisfied", "satisfied", and "very satisfied". 
To find out the influence of structural variable on job satisfaction, we employ the simple regression technique using SmartPLS software. The influence significance test is affirmed by the $t$ value which should be bigger than 1.96. If the $t$ value is not bigger than 1.96 , then it is concluded that the influence is not significant. Before performing the influence test, we perform validity test by observing convergent validity and discriminating validity, and reliability test by observing the value of composite reliability.

A model which has good convergent validity is a model whose variable has the loading factor above 0.5 for each indicator. A good discriminating validity is indicated by the AVE root value which is bigger than the correlation between variables. And a model can be considered reliable if it has a composite reliability value which is bigger than 0.7 .

\section{RESULT OF THE STUDY AND DISCUSSION}

Based on the processed data from the questionnaires, we find the following respondents' descriptive profile:

1. Sex

Table 1. Sex

\begin{tabular}{lcc}
\hline & Frequency & Percentage \\
\hline Male & 60 & 60.0 \\
Female & 40 & 40.0 \\
\hline Total & 100 & 100.0 \\
\hline
\end{tabular}

The descriptive data shows that 60 respondents of the total respondents $(60 \%)$ are male and the rest 40 respondents (40\%) are female.

2. Age

Table 2. Age

\begin{tabular}{lcc}
\hline & Frequency & Percentage \\
\hline$<=25$ years old & 8 & 8.0 \\
26-35 years old & 41 & 41.0 \\
36-45 years old & 28 & 28.0 \\
$>=46$ years old & 23 & 23.0 \\
\hline Total & 100 & 100,0 \\
\hline
\end{tabular}

From the respondent age data it can be seen that 8 respondents (8\%) are 25 or less than 25 years old. 41 respondents $(41 \%)$ are between $26-35$ years old. 28 respondents (28\%) are between 36-45 years old. Tthe rest 23 respondents (23\%) are 46 or more than 46 years old.

3. Work duration

Work duration data shows that eight respondents $(8 \%)$ have worked in the hotels for three years. 26 respondents (26\%) have worked from three years one month to five years. 22 respondents $(22 \%)$ have worked from five years one month to seven years. 11 respondents $(11 \%)$ have worked seven years one month to nine years. 12 respondents (12\%) have worked from nine years one month to 11 years. The rest 21 respondents $(21 \%)$ have worked for more than 11 years.

Table 3. Work duration

\begin{tabular}{lcc}
\hline & Frequency & Percentage \\
\hline 3 years & 8 & 8.0 \\
3 years, 1 month-5 years & 26 & 26.0 \\
5 years, 1month-7 years & 22 & 22.0 \\
7 years, 1month-9 years & 11 & 11.0 \\
9 years, 1month-11years & 12 & 12.0 \\
$>$ 11 years & 21 & 21.0 \\
\hline Total & 100 & 100.0 \\
\hline
\end{tabular}

4. Salary

Table 4. Salary (in Indonesian Rupiah)

\begin{tabular}{lcc}
\hline & Frequency & Percentage \\
\hline$<=2,500,000$ & 4 & 4.0 \\
$2,500,001-3,500,000$ & 20 & 20.0 \\
$3,500,001-4,500,000$ & 45 & 45.0 \\
$>4,500,000$ & 31 & 31.0 \\
\hline Total & 100 & 100.0 \\
\hline
\end{tabular}

From the salary data we find that 4 respondents (4\%) receive the salary of 2.5 million rupiahs or less. 20 respondents $(20 \%)$ receive between $2.5-$ 3.5 million rupiahs. 45 respondents $(45 \%)$ receive between 3.5-4.5 million rupiahs, while the other 31 respondents $(31 \%)$ receive more than 4.5 million rupiahs.

5. Marital Status

Table 5. Marital Status

\begin{tabular}{lcc}
\hline & Frequency & Percentage \\
\hline Married & 66 & 66.0 \\
Single & 34 & 34.0 \\
\hline Total & 100 & 100.0 \\
\hline
\end{tabular}

From the marital status we find that 66 respondents $(66 \%)$ are married and the other 34 respondents (34\%) are single.

6. Number of Children

Table 6. Number of Children

\begin{tabular}{lrr}
\hline & Frequency & Percentage \\
\hline No children & 42 & 42.0 \\
1 child & 18 & 18.0 \\
2 children & 25 & 25.0 \\
3 children & 13 & 13.0 \\
$>=4$ children & 2 & 2.0 \\
Total & 100 & 100,0 \\
\hline
\end{tabular}


Table 6 shows that 42 respondents $(42 \%)$ do not have children. 18 respondents $(18 \%)$ have one child. 25 respondents (25\%) have two children. 13 respondents $(13 \%)$ have three children and the rest two respondents $(2 \%)$ have four or more than four children.

From data processing we obtain the mean result of the perception towards structural variable as given in Table 7.

Table 7. The Mean Value of Structural Indicator

\begin{tabular}{lcc}
\hline Structural & Mean & Category \\
\hline $\begin{array}{l}\text { Fellow employees support me in } \\
\text { doing my job }\end{array}$ & 4.02 & High \\
$\begin{array}{l}\text { My supervisor supports me in doing } \\
\text { my job }\end{array}$ & 4.02 & High \\
$\begin{array}{l}\text { My job is not so routine that it be- } \\
\text { comes boring }\end{array}$ & 3.75 & High \\
$\begin{array}{l}\text { The management treats me justly } \\
\text { Total }\end{array}$ & 3.85 & High \\
\hline
\end{tabular}

The table indicates that employees' perception of structural variable is high. There are two points which have the highest value, namely support from fellow employees and support from supervisor, which is 4.02. The lowest value is employees' job routine which is 3.75 , which still belongs to high category.

We also process the data about the job satisfaction of 4 and 5 starred hotels' employees in Surabaya. The result of data processing is given in Table 8 .

Table 8. The Mean Value of Job Satisfaction Indicator

\begin{tabular}{lcc}
\hline Job Satisfaction & Mean & Category \\
\hline $\begin{array}{l}\text { My salary is satisfying } \\
\text { I am satisfied with my fellow } \\
\text { employees }\end{array}$ & 3.02 & Satisfied \\
$\begin{array}{l}\text { My supervisor is highly compe- } \\
\text { tent in performing his/her tasks }\end{array}$ & 3.68 & Satisfied \\
$\begin{array}{l}\text { I am given chances for promo- } \\
\text { tion in my job }\end{array}$ & 3.84 & Satisfied \\
$\begin{array}{l}\text { My working condition is con- } \\
\text { ducive }\end{array}$ & 3.95 & Satisfied \\
$\begin{array}{l}\text { I am allowed to make decisions } \\
\text { concerning my job }\end{array}$ & 3.75 & Satisfied \\
\hline Total & 3.85 & Satisfied \\
\hline
\end{tabular}

Table 8 shows that the job satisfaction of 4 and 5 starred hotels in Surabaya is high. The highest value is in salary indicator which is 4.02. The indicator with the lowest value is supervisor's competence in performing his or her tasks.

Before performing hypothesis test, we perform validity test. In the result of the convergent validity test there is one indicator, namely $X_{11}$ which does not meet the convergent validity requirement since it has a value smaller than 0.5 . In the next phase of the study, this indicator is discarded. After indicator $X_{11}$ is discarded, the values of all loading factors are bigger than 0.5 . Thus, the adjusted model has a good convergent validity. Then we perform discriminating validity test by observing the AVE root value. The calculation of AVE root value and the picture of the initial model are as shown on Figure 2.

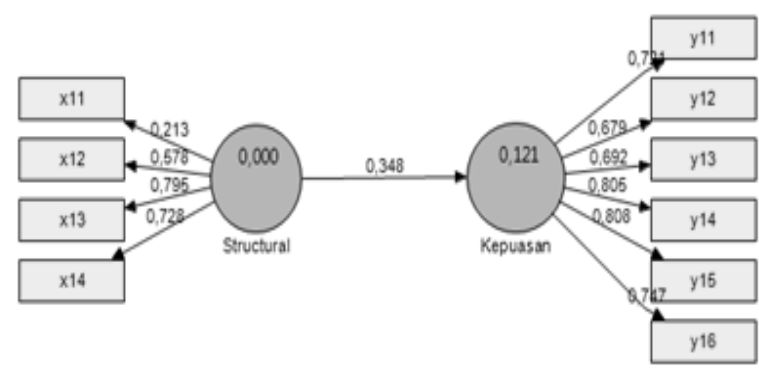

Figure 2. The Initial Model of the Study

Note: Kepuasan = Satisfaction

Table 9. AVE root

\begin{tabular}{lrr}
\hline & AVE & AVE root \\
\hline & 0.5532 & 0.743774 \\
Structural Satisfaction & 0.4992 & 0.706541 \\
\hline
\end{tabular}

We can see that the model has a fairly high AVE root value. This value will be compared to the correlation value between variables:

Table 10. Correlation between Variable

\begin{tabular}{lcc}
\hline & Satisfaction & Structural \\
\hline Satisfaction & 1 & 0 \\
Structural & 0,35 & 1 \\
\hline
\end{tabular}

Table 9 and 10 show that the correlation value of structural variable and satisfaction variable is 0.35 . This value is lower than the AVE root value. Thus we can conclude that the model has a good discriminating validity. After performing validity test, we perform reliability test by observing the composite reliability value which is shown in Table 11 .

Table 11. Composite Reliability

\begin{tabular}{lc}
\hline & Composite Reliability \\
\hline Satisfaction & 0.8809 \\
Structural & 0.7460 \\
\hline
\end{tabular}

The composite reliability values of satisfaction variable and structural variable are higher than 0.7 . Thus, we can conclude that the model has a good reliability. The following is the picture of the model which has passed the validity and reliability test. 


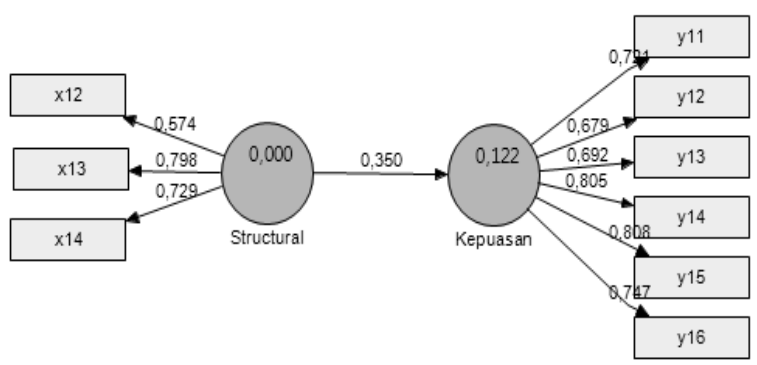

Figure 3. The Result of PLS Algorithm

Note: Kepuasan $=$ Satisfaction

Figure 3 shows that the $\mathrm{R}$ squared value of satisfaction variable is 0.122 . This means that job satisfaction can be explained by structural variable as much as $12.2 \%$, and the rest is explained by other variables not examined in this study.

\section{Hypothesis Test}

For hypothesis test, in the model we utilize bootstrapping process to calculate the $t$ value. The result of bootstrapping can be seen in Table 12 .

Table 12. $t$ Value

\begin{tabular}{lcc}
\hline & $\begin{array}{c}\text { Original } \\
\text { Sample }(\boldsymbol{O})\end{array}$ & $\begin{array}{c}\text { T Statistics } \\
(|\boldsymbol{O} / \mathrm{STERR}|)\end{array}$ \\
\hline Structural $\rightarrow$ Satisfaction & 0.35 & 5.29 \\
\hline
\end{tabular}

From the bootstrapping process we can see that the value of original sample or the value of weight factor is 0.35 and the $t$ value is 5.29. A $t$ value that is bigger than 1.96 indicates that structural variable has a significant influence on satisfaction variable, while a weight factor with a positive value indicates that structural variable has a positive influence on satisfaction variable. This means that the better the structural variable, the higher the employees' satisfaction. Thus, the hypothesis of this study that structural variable has influence on employees' satisfaction can be accepted.

\section{Discussion}

From the data processing we find that in overall, employees' perception of structural variable and the job satisfaction of 4 and 5 starred hotels' employees in Surabaya is high. This is confirmed by the overall values of the two variables observed subsequently, which are 3.87 and 3.85 which belongs to high interval. Thus, globally, employees consider that the management systems of the hotels are good. Further, employees also feel satisfied with their jobs.
Beside that, the result of the test of structural variable's effect on job satisfaction shows that structural variable has a positive and significant effect on job satisfaction. This is proved by the $t$ value of 5.29 which is bigger than 1.96 , and by a positive weight factor. This result confirms the former result which shows that employees have good perceptions of the working system applied in 4 and 5 starred hotels in Surabaya, and they also have high job satisfaction.

This finding confirms the causal model of Iverson \& Deery (2007) which proposes that positive support from supervisor and fellow employees, the job itself, and just treatment of the management will promote higher job satisfaction among employees. While doing his or her daily job, an employee will be always in contact with the job itself, interact with his or her supervisor and with his or her fellow employees, while the company also contributes in the form of policies. These conditions will be judged by the employees. If they consider that the conditions are not satisfying, their job satisfaction will decrease, or the other way round.

Interviews to five employees confirm the conclusion of this study. The majority of the employees state that fellow employees and direct supervisor comprise the reasons why they like to work in a certain hotel. If the direct supervisor and fellow employees are people with whom the employee feel at ease, then the employ will feel that the management is really supporting himself or herself by placing those people around him or her. This agrees with the statement of Iverson \& Deery (2007) which says that management should support employees and should take care of support from fellow employees to other fellow employees.

On the other hand, there is a disagreement about job routine. Four of the five employees interviewed state that job tasks in hotels are routine. This is inconsistent with the statement of Iverson \& Deery (2007) about job routine. However, the employees also express that although the job tasks in hotels are routine, every day they serve different guests. This makes the job not so routine. Therefore they regard the job as a dynamic job and consequently not routine. Besides that, several employees also say that sometimes they are placed in other outlets of the hotel. This causes the job to lose its routine nature. However, job routine should be taken care by hotel management because this concerns job design, which may cause a job to appear routine or not.

In job satisfaction variable, the highest value is obtained by satisfaction towards salary. We make further interviews concerning this since from respondents' profile we find that the salaries received by 
the employees are not high. $4 \%$ of the employees even receive less than Rp.2,500,000,- and the highest percentage are employees who receive salaries between Rp.3,500,001,- and Rp.4,500,000,--. From the interviews we find that satisfaction towards salary is high because in answering the questionnaire, the employees also include the service charge which is given to the employees monthly. However, in completing employee's profile, they only include the basic salary given by the hotel management. While the value of service charge is fairly high, at most times the service charge is even higher that the basic salary. The service charge is determined by hotel occupancy rate.

The lowest satisfaction value is in supervisor's competence indicator, although the value still belongs to the high category. This usually occurs because the supervisor who is in charge of the hotel operational is usually an employee of the operational departments who is promoted to position of supervisor. In front of the house operational, a supervisor who has experience in that tasks is of course competent. However, the result of the interviews also indicates that managerial activities such as forecasting and scheduling are not performed well by the supervisor, which results in mistakes.

\section{CONCLUSION AND SUGGESTION}

From the result of the study we can draw the following conclusions:

1. Employees' perceptions of the structural variable of 4 and 5 starred hotels in Surabaya are high, with the mean value of 3.87 .

2. Job satisfaction values of the employees of 4 and 5 starred hotels in Surabaya are high, with the mean value of 3.85 .

3. Structural variable indicator with the highest mean value is support from fellow employees and from supervisor, while the indicator with the lowest mean value is job routine.

4. Job satisfaction indicator with the highest mean value is satisfaction towards salary, while the indicator with the lowest mean value is supervisor competence in performing his or her tasks.

5. Structural variable has a positive and significant effect on the job satisfaction of the employees of 4 and 5 starred hotels in Surabaya.

\section{Suggestions}

Based on the conclusions of this study, we would like to propose the following suggestions:

1. The hotel management should take care of the job design in their hotel since from the interviews we find that hotel jobs are considered routine.
2. Organize managerial trainings for supervisors who are promoted from operational employees.

3. For further study we would like to suggest a study of the effect of structural variable on the job satisfaction of the employees of 4 and 5 starred hotels in Surabaya.

4. We also propose to study further employees' perception of structural variable and employees' job satisfaction in 3 or less than 3 starred hotels in Surabaya, including the hotels' budgets.

\section{REFERENCES}

Aamodt, M. G. 2004. Applied Industrial Organizational Psychology. USA: Thomson-Wadsworth.

Astrauskaite, M., Vaitkevičius, R., \& Perminas, A. 2011. Job Satisfaction Survey: A Confirmatory Factor Analysis Based on Secondary School Teachers' Sample. International Journal of Business and Management, 6(5): 41-50.

Cranny, C. J., Smith, P. C., \& Stone, E. F. 1992. Job Satisfaction: How People Feel about Their Jobs and How It Affects Their Performance. New York, NY: Lexington Books.

Currivan, D. B. 2000. The Causal Order of Job Satisfaction and Organizational Commitment in Models of Employee Turnover. Human Resource Management Review, 9(4): 495-524.

Datta, P. 2012. An Applied Organizational Rewards Distribution System. Management Decision, 50(3): 479-501.

Hom, P. W. \& Griffeth, R. W. 1995. Employee Turnover. Ohio: South-Western College.

Iverson, R. D. \& Deery, M. 2007. Turnover Culture in the Hospitality Industry. Human Resource Management Journal, 7(4): 71-82.

Johns, G. 1996. Organizational Behaviour: Understanding and Managing Life at Work. Kansas City: Harper Collins College Publisher.

Kandampully, J. \& Suhartanto, D. 2000. Customer Loyalty in the Hotel Industry: The Role of Customer Satisfaction and Image. International Journal of Contemporary Hospitality Management, 12(6): 346-351.

Kartika, E. W. \& Kaihatu, T. 2010. Analisis Pengaruh Motivasi Kerja terhadap Kepuasan Kerja (Studi Kasus pada Karyawan Restoran di Pakuwon Food Fest Surabaya). Jurnal Manajemen dan Kewirausahaan, 12(1): 100-112.

Kotler, P. \& Armstrong, G. 1997. Marketing: An Introduction. Upper Saddle River, NJ: PrenticeHall.

Mahardika, G. 2006. Pengaruh Person-Organization Fit (Kecocokan Nilai-nilai Individu dengan Nilai-nilai Organisasi) terhadap Kepuasan 
Kerja, Komitmen Organisasi, dan Kinerja Karyawan (Studi pada RSI PKU Muhammadiyah Pekalongan). Tesis tidak dipublikasikan. Semarang: Universitas Diponegoro.

Perkembangan Pariwisata dan Transportasi Nasional. Maret 2013. Berita Resmi Statistik, No. 29(5), Th. XVI.

Purnomo, H. 2012. Jumlah Ekspatriat Melonjak, Bisnis Properti Moncer, (http://finance.detik. com/read/2012/01/19/123208/1819784/1016/ jumlah-ekspatriat-melonjak-bisnis-proopertimoncer, diakses 3 Oktober 2012).

Riketta, M. 2002. Attitudinal Organizational Commitment and Job Performance: A Meta Analysis. Journal of Organizational Behaviour, 23(3): 257-266.

Schwepker Jr., C.H. 2001. Ethical Climate's Relationship to Job Satisfaction, Organizational Commitment, and Turnover Intention in the Salesforce. Journal of Business Research, 54(1): 39-52.

Sekaran, U. 2006. Metode Penelitian Bisnis. Jakarta: Salemba Empat.

Sha, N. 2007. A Study of the Relationships between Job Satisfaction and Procedural Justice Experienced by Employees in a Brick Manufacturing
Company and Their Organiza-tional Citizenship Behaviour. Unpublished Disertation. Western Cape: University of Western Cape.

Spector, P.E. 1997. Job Satisfaction: Application, Assessment, Causes and Consequences. New York: Harper \& Row.

30 Hotel Baru Menyerbu. 2012. Retrieved 3 October 2012 from http://www.surabayapost. co.id/?mnu =berita\&act=view\&id=a4b8ab86ad3bdd1ff072 5be9e465a1cf\&jenis $=$ d41d8cd98f00b204e9800 998ecf8427e.

Timmreck, T. C. 2001. Managing Motivation and Developing Job Satisfaction in the Health Care Work Environment. The Health Care Manager, 20(1): 42-58.

Wahyuni, D. 2011. Hotel di Surabaya Kian Ketat Bersaing, (http://www.bisnis.com/articles/ hoteldi-surabaya-kian-ketat-bersaing, diakses 2 Oktober 2012).

Weiss, H. M. 2002. Deconstructing Job Satisfaction: Separating Evaluations, Beliefs and Affective Experiences. Human Resource Management Review, 12: 173-194. 